\title{
Effect of nutrients management on yield attributes of fodder beet under sandy soil conditions.
}

\author{
Abd El-Lattief , E. A. *, M. A. Ali, and. A.M. Ali \\ Agronomy department, Faculty of Agriculture, South Valley University, Qena, Egypt.
}

\begin{abstract}
The effect of chemical fertilizer (NK) and humic acid on top length, root length, root diameter, leaf area per plant, top fresh \& dry weight and root fresh \& dry weight of fodder beet (Beta vulgaris L. c.v voroshinger) was carried out in the Experimental Farm of Agriculture Faculty, South Valley University at Qena during the two seasons of 2016/2017 and 2017/2018 on sandy soil. A field experiment was conducted using a randomized complete block design in split- plots arrangement with three replications. Humic acid treatments were arranged in main plots while, fertilization treatments $(\mathrm{NK})$ were allocated in sub-plots. The highest mean values of most previous traits were obtained from fodder beet plants which were supplemented by soil application of humic acid and $90 \mathrm{~kg} \mathrm{~N}+100 \mathrm{~kg} \mathrm{~K} 2 \mathrm{O} / \mathrm{fed}$. $\left(\mathrm{H}_{1} \mathrm{~F}_{9}\right)$. Based on these results, it is recommended to adding humic acid on soil and fertilization with $\mathrm{NK}$ by $90 \mathrm{Kg} \mathrm{N}+100 \mathrm{~kg} \mathrm{~K}_{2} \mathrm{O}$ per Feddan for fodder beet under similar soil and climate conditions.
\end{abstract}

Keywords: Fodder beet, Fertilization, Sandy soil

\section{Introduction}

Fodder beet (Beta vulgaris L.) is a member of the Chenopodiaceae family. Fodder beet is one of the promising winter forage crop in Egypt, especially under limited water and nutrients levels (Noreldin et al, 2016). All parts of fodder beet plant (foliage and roots) are used in animal feeding, whether directly or processed as silage (Sakr et al, 2014). The advantage of cultivating fodder beet is that it produces high economic yield in marginal lands (Abdallah and Yassen, 2008). Thus, its cultivation may help in overcoming the problem of feed shortage in Egypt during summer season (El-Sarag, 2013). Fodder beet is successfully grown as a fodder crop in many European countries and in Egypt also. The plant is used as a valuable source of fodder for cattle (Niazi, et al, 2000). Since

*Corresponding author: E.A. Abdel-lattief

essameldeen@agr.svu.edu.eg

Received: June 22, 2020;

Accepted: August 11, 2020;

Published: September 4. 2020. fodder beet contains high water and sugar, it increases milk product and is suitable forage for dairy cows. The fodder beet is used by mixing with straw in European and other countries. It is also reported that the plant is suitable to make silage (Özen et al, 1993). Fodder beet has extremely high yield potential when grown on high fertile soils.

Humic acid is extracted from different sources such as soil, Humus, peat, oxidized lignite, and coal. Humic acid can directly have positive effects on plant growth and increases the growth of shoots and roots, absorption of nitrogen, potassium, calcium, magnesium, and phosphorus by plant. Humic acid is consistent with nature and is not dangerous for the plant and environment (Haghighi et al, 2013). AbdelMawgoud et al, (2007) states that humic acid increases plant growth through chelating different nutrients to overcome the lack of 
nutrients, and has useful effects on growth increase, production, and quality improvement of agricultural products due to having hormonal compounds.

Fodder beet requires large amounts of nitrogen. Several studies were carried out to determine the effect of Nitrogen fertilizers on fodder beet. Nitrogen fertilizers are one of the major costs for production of these crops (Abdel Gwad et al, 2008). Zamfir, et al (2001) reported that increasing nitrogen fertilization increased dry matter yield and crude protein content of fodder beet.

Potassium is an important element in plant nutrition, especially those having carbohydrate storage such as sugar beet and fodder beet, Also, $\mathrm{K}$ is a co-factor activating a number of important enzymes which are involved in many processes in plants such as photosynthesis, respiration and carbohydrate metabolism and translocation. Many investigators reported that $K$ fertilizers had progressive effect on fodder or sugar beet growth and yield criteria (Gamal and Ragab, 2003). The influence of soil fertilization on nutrient content in crops has been studied and different results have been recorded. Some authors show that the application of organic amendment improves soil nutrient content, but does not always increases plant nutrient concentration.

Growth characters and yield and or yield attributes of fodder beet responded positively to the fertilization with NPK fertilizers (Abd ElAll, 1990).

Therefore, the objective of this investigation was to study the effect of NK fertilization rates and Humic acid (foliar or soil application) on yield attributes of fodder beet under Qena conditions.

\section{Materials and Methods}

A field experiments was conducted in the Experimental Farm of Agriculture Faculty, South Valley University, at Qena Governorate, Egypt, during the two successive winter seasons of (2016/2017 and 2017/2018). The farm is located at an altitude of $79 \mathrm{~m}$ above mean sea level and is intersected by $26^{\circ} 10^{\prime} \mathrm{N}$ latitude and $32^{\circ} 43^{\prime}$ E longitude. The experiment included three Humic acid treatments $\left(\mathrm{H}_{0^{-}}\right.$Without Humic acid, $\mathrm{H}_{1}$ - soil application, $\mathrm{H}_{2}$ - foliar application). and nine fertilizers (NK) treatments (1- 30kg N+0kg $\mathrm{K}_{2} \mathrm{O} /$ fed., $2-30 \mathrm{~kg}$ $\mathrm{N}+50 \mathrm{~kg} \mathrm{~K} 2 \mathrm{O} /$ fed., 3- 30kg N+100kg K $2 \mathrm{O} /$ fed., 4- $60 \mathrm{~kg} \mathrm{~N}+0 \mathrm{~kg} \mathrm{~K}_{2} \mathrm{O} / \mathrm{fed}$, $5-60 \mathrm{~kg} \mathrm{~N}+50 \mathrm{~kg}$ $\mathrm{K}_{2} \mathrm{O} /$ fed., 6- $60 \mathrm{~kg} \mathrm{~N}+100 \mathrm{~kg} \mathrm{~K}{ }_{2} \mathrm{O} /$ fed., 7- $90 \mathrm{~kg}$ $\mathrm{N}+0 \mathrm{~kg} \mathrm{~K} \mathrm{~K}_{2} \mathrm{O} /$ fed., 8- 90kg N+50kg $\mathrm{K}_{2} \mathrm{O} /$ fed., 9- $90 \mathrm{~kg} \mathrm{~N}+100 \mathrm{~kg} \mathrm{~K}_{2} \mathrm{O} /$ fed.). The soil of the experimental site is sandy soil throughout its profile $(73.7 \%$ coarse sand, $16.8 \%$ fine sand, $5.8 \%$ silt and $3.7 \%$ clay), with a $\mathrm{pH}$ value of $8.17,0.44$ EC (dSm-1), $0.89 \%$ organic matter content, $0.32 \%$ total $\mathrm{N}, 8.22$ and $10.38 \mathrm{ppm}$ available $\mathrm{P}$ and $\mathrm{K}$, respectively.

The experimental design was randomized complete block design (RCBD) using splitplots arrangement with three replications. Three treatment of humic acid were distributed in main plots while, nine treatments of NK fertilization levels were allocated on the subplots. The experimental unit area was $9 \mathrm{~m}^{2}$ (1/500 fad) containing 4 rows of $3 \mathrm{~m}$ length and $50 \mathrm{~cm}$ between rows and $15 \mathrm{~cm}$ between plants. Seeds of fodder beet (Beta vulgaris L.) c.v. voroshinger (Hungarian) were sown at the rate of $4 \mathrm{~kg} / \mathrm{fed}^{-1}$ on November $25^{\text {th }}$ in the $1^{\text {st }}$ and $2^{\text {nd }}$ seasons. Seeds were planted on top of the shoulder of the ridge ( 3 seeds per hole). After one month, the plants were thinned to 3-9 plants per hill, and then were singled to one plant per hill after 45 days from sowing, and reshowing by the removed seedlings were done simultaneously after 5-6 weeks from planting during both seasons.

Humic acid was added at the rate of $2 \mathrm{~kg} / \mathrm{fed}$. soil or foliar application after one month from sowing. Mineral fertilization nitrogen in the form of ammonium nitrate $33.5 \% \mathrm{~N}$, and potassium in the form of potassium sulphate 
$48 \% \mathrm{~K}_{2} \mathrm{O}$. Treatments were added for mixing broadcasted twice doses, the first dose after one month and the second dose after two month from sowing. Triple superphosphate $(15.5 \%$ $\mathrm{P}_{2} \mathrm{O}_{5}$ ) was added pre-planting at the rate of 150 $\mathrm{kg} / \mathrm{fed}$. before sowing. The other cultural practices were carried out as recommended for the crop.

At harvest time (5 months from sowing), when plants showed signs of maturity which is indicated by leaf yellowing and partial drying of the lower leaves, five plants were taken from each sub plot randomly hand pulled, separated into roots and tops to determine the following characters:

1) Leaves area/plant $\left(\mathrm{cm}^{2}\right)$ : The disk method was followed using 100 disks of $1 \mathrm{~cm}$ diameter then total leaf area per plant was calculated according to blades dry weights (Watson and Watson, 1953).

2) Top length/plant $(\mathrm{cm})$.

3) Top fresh weight/plant (g).

4) Top dry weight/plant (g).

5) Root length $(\mathrm{cm})$.

6) Root diameter $(\mathrm{cm})$.

7) Root fresh weight/plant (g).

8) Root dry weight/plant (g).

Data were analyzed by standard analysis of variance (ANOVA) were carried out according to Gomez and Gomez, (1984) using MSTAT Computer Program v.4 (1986). Means were compared using Least Significant Difference (LSD) procedures at 5\% level of probability.

\section{Results and Discussion}

\section{1- Leaves area/plant $\left(\mathrm{cm}^{2}\right)$ :}

Data listed in Table 1 denote that the soil application of humic acid treatment had a significant effect on leaf area/plant $\left(\mathrm{cm}^{2}\right)$ in the first season only. The application of humic acid on soil did not differ significantly from foliar spray treatment. The highest leaf area/plant $\left(9489.16 \mathrm{~cm}^{2}\right)$ was obtained from soil application of humic acid and the lowest leaf area/plant $\left(6894.39 \mathrm{~cm}^{2}\right)$ without humic acid application in the first season. This may be due to increase the photosynthetic surface per unit area which, promoted growth and nutrient uptake of plants by addition of humic substances which affect membrane permeability. The aforementioned results generally are in good agreement with those stated by Anuja and Jayalakshmi (2011), Shaban et al (2014), El-gamal et al (2016), and Ozbay and Murat (2018).

Regarding to the effect of NK treatments, the data in Table 1 clear that the NK fertilization treatments had a significant effect on leaf area/plant $\left(\mathrm{cm}^{2}\right)$ in both seasons. Thus F9 treatment $(90 \mathrm{~kg} \mathrm{~N}+100 \mathrm{~kg} \mathrm{~K} 2 \mathrm{O} /$ fed.) achieved maximum increase in leaf area/plant which was 10395.53 and $6009.65 \mathrm{~cm}^{2}$ in the first and second seasons, respectively. Whereas, minimum leaf area/plant (6810.57 and $3173.23 \mathrm{~cm}^{2}$ in the two respective seasons) were recorded from $\mathrm{F} 1$ treatment $(30 \mathrm{~kg} \mathrm{~N}+0 \mathrm{~kg} \mathrm{~K} 2 \mathrm{O}$ /fed.). The increase in leaf area as a result high rates of NK treatments may be referred to their effect on nitrogen fixation and the uptake of nutrients hence increased fodder beet growth and development. These findings are in fully accordance with results of Geweifel and Aly (1996), Sahar (2000), Hussein and Hanan (2012), Shaban et al (2014), Tamiru et al (2017). The interaction between humic acid and NK treatment $(\mathrm{H} \times \mathrm{F})$ had a significant effect on leaf area trait in the both seasons. The highest mean values of leaves area/plant (11163 and $6848 \mathrm{~cm}^{2}$ in the two respective seasons) were obtained from fodder beet plants which were supplemented by $90 \mathrm{~kg} \mathrm{~N}$ and $100 \mathrm{~kg} \mathrm{~K} 2 \mathrm{O} /$ fed. with humic acid soil application in the first season and by the same $\mathrm{Nk}$ treatment with humic acid foliar spray in the second one. 
Table 1. Effects of humic acid, NK treatments and their interaction on leaf area/plant $\left(\mathrm{cm}^{2}\right)$ of fodder beet in 2016-2017 and 2017-2018 seasons.

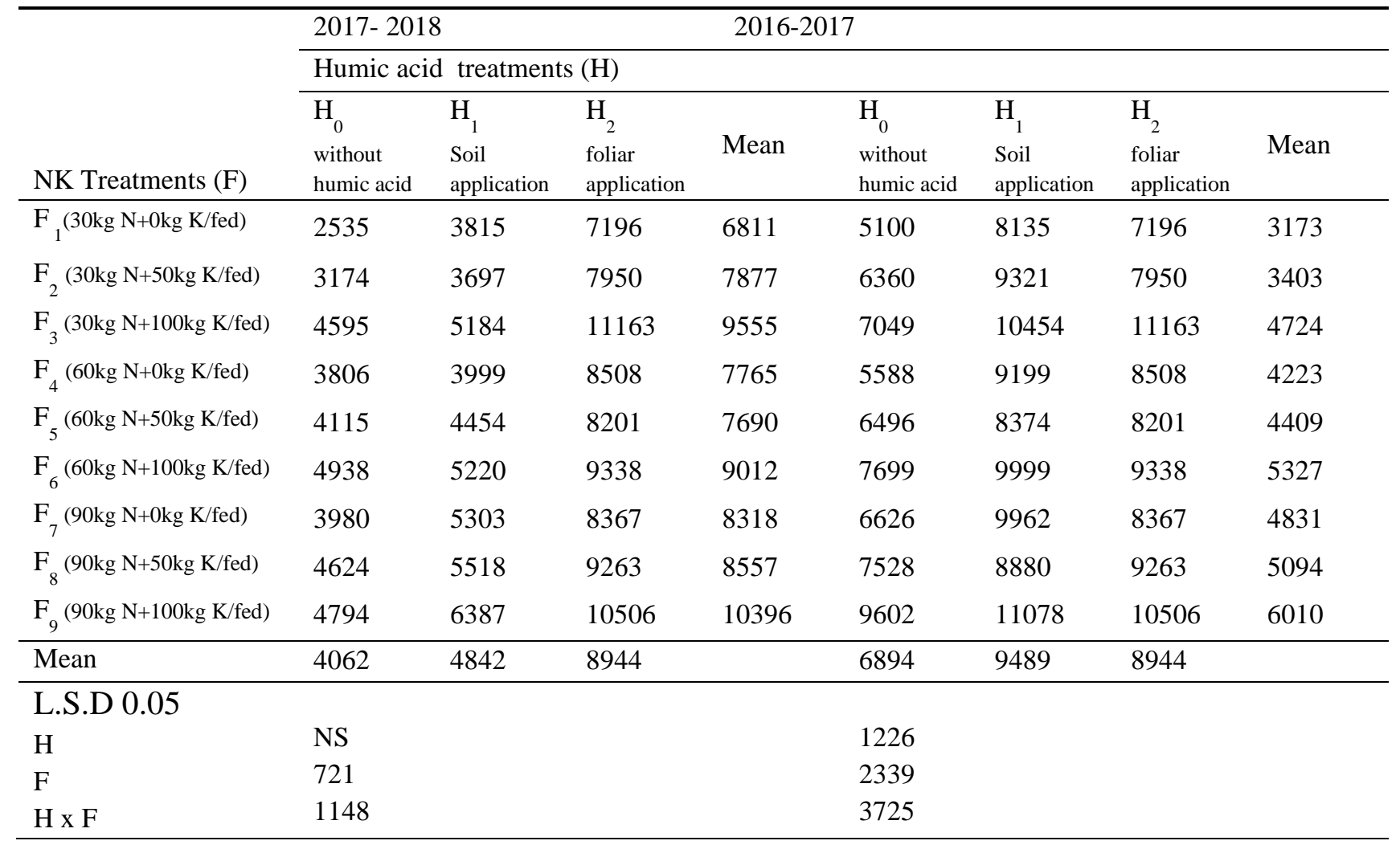

The significant response could be attributed to a different trend of response which was observed in plants of application humic under NK treatments.

\section{2-Top length (cm):}

Data illustrated in Table 2 indicate that application of humic acid had a significant effect on top length in the second season only. Soil application of humic acid did not differ significantly with the humic acid foliar spray. Soil application of humic acid recorded the highest mean value of top length $(43.1 \mathrm{~cm})$ in the second season compared with control $(37.3 \mathrm{~cm})$. This result may be ascribed to the possibility that humic substances may enhance the uptake of some nutrients. These results are in according to Anuja and Jayalakshmi (2011).
Furthermore, data presented in Table 2 reveal that increasing $\mathrm{NK}$ treatment levels up to $90 \mathrm{~kg} \quad \mathrm{~N}+100 \mathrm{~kg} \quad \mathrm{~K}_{2} \mathrm{O} / \mathrm{fed}$ significantly increased top length in both seasons. The tallest fodder beet plants $(47.6$ and $48.1 \mathrm{~cm}$, in the two respective seasons) were obtained from $\mathrm{F}_{9}$ treatment $\left(90 \mathrm{~kg} \mathrm{~N}+100 \mathrm{~kg} \mathrm{~K}_{2} \mathrm{O} /\right.$ fed.). The increase in top length as a result of high levels of NK treatments may be referred to nitrogen fertilization enhanced plant capacity in protein synthesis and encouraging cell division, where, fodder beet responded positively to these building up roles of nitrogen These results are in agreement with those obtained by Sahar (2000), Turk (2010), Hussein and Hanan (2012), Kassab et al (2012) Khogali et al (2012), and Eman El-Sarag (2013).

Table 2: Effects of humic acid, NK treatments and their interaction on top length $(\mathrm{cm})$ of fodder beet in 2016-2017 and 2017-2018 seasons. 


\begin{tabular}{|c|c|c|c|c|c|c|c|c|}
\hline \multirow{3}{*}{$\begin{array}{l}\text { NK } \\
\text { Treatments (F) }\end{array}$} & \multicolumn{4}{|l|}{$2016-2017$} & \multicolumn{4}{|l|}{ 2017- 2018} \\
\hline & \multicolumn{8}{|c|}{ Humic acid treatments $(\mathrm{H})$} \\
\hline & $\begin{array}{l}\mathrm{H}_{0} \\
\text { without } \\
\text { humic acid }\end{array}$ & $\begin{array}{l}\mathrm{H}_{1} \\
\text { Soil } \\
\text { application }\end{array}$ & $\begin{array}{l}\mathrm{H}_{2} \\
\text { foliar } \\
\text { application }\end{array}$ & Mean & $\begin{array}{l}\mathrm{H}_{0} \\
\text { without } \\
\text { humic acid }\end{array}$ & $\begin{array}{l}\mathrm{H}_{1} \\
\text { Soil } \\
\text { application }\end{array}$ & $\begin{array}{l}\mathrm{H}_{2} \\
\text { foliar } \\
\text { application }\end{array}$ & Mean \\
\hline $\mathrm{F}_{1}(30 \mathrm{~kg} \mathrm{~N}+0 \mathrm{~kg} \mathrm{~K} / \mathrm{fed})$ & 37.33 & 41.20 & 41.00 & 39.84 & 30.73 & 39.47 & 37.40 & 35.87 \\
\hline $\mathrm{F}_{2}(30 \mathrm{~kg} \mathrm{~N}+50 \mathrm{~kg} \mathrm{~K} / \mathrm{fed})$ & 39.67 & 42.67 & 42.07 & 41.46 & 32.13 & 41.07 & 39.80 & 37.67 \\
\hline $\mathrm{F}_{3}(30 \mathrm{~kg} \mathrm{~N}+100 \mathrm{~kg} \mathrm{~K} / \mathrm{fed})$ & 43.40 & 45.67 & 45.40 & 44.82 & 40.60 & 42.67 & 42.67 & 41.98 \\
\hline $\mathrm{F}_{4}(60 \mathrm{~kg} \mathrm{~N}+0 \mathrm{~kg} \mathrm{~K} / \mathrm{fed})$ & 39.00 & 43.00 & 43.33 & 41.77 & 31.07 & 38.93 & 39.20 & 36.40 \\
\hline $\mathrm{F}_{5}(60 \mathrm{~kg} \mathrm{~N}+50 \mathrm{~kg} \mathrm{~K} / \mathrm{fed})$ & 42.00 & 44.33 & 44.07 & 43.46 & 35.47 & 42.33 & 40.53 & 39.42 \\
\hline $\mathrm{F}_{6}(60 \mathrm{~kg} \mathrm{~N}+100 \mathrm{~kg} \mathrm{~K} / \mathrm{fed})$ & 45.00 & 46.40 & 46.07 & 45.82 & 41.67 & 46.47 & 43.93 & 44.02 \\
\hline $\mathrm{F}_{7}(90 \mathrm{~kg} \mathrm{~N}+0 \mathrm{~kg} \mathrm{~K} / \mathrm{fed})$ & 42.07 & 44.20 & 42.47 & 42.91 & 39.60 & 42.73 & 42.87 & 41.73 \\
\hline $\mathrm{F}_{8}(90 \mathrm{~kg} \mathrm{~N}+50 \mathrm{~kg} \mathrm{~K} / \mathrm{fed})$ & 44.33 & 45.80 & 45.40 & 45.17 & 40.53 & 43.33 & 43.67 & 42.51 \\
\hline $\mathrm{F}_{9}(90 \mathrm{~kg} \mathrm{~N}+100 \mathrm{~kg} \mathrm{~K} / \mathrm{fed})$ & 46.67 & 48.07 & 48.00 & 47.57 & 44.07 & 50.67 & 49.53 & 48.09 \\
\hline Mean & 42.16 & 44.59 & 44.20 & & 37.32 & 43.07 & 42.18 & \\
\hline \multicolumn{9}{|l|}{ LSD 0.05} \\
\hline $\mathrm{H}$ & NS & & & & 1.40 & & & \\
\hline $\mathrm{F}$ & 3.14 & & & & 1.95 & & & \\
\hline $\mathrm{H} \times \mathrm{F}$ & 5.45 & & & & NS & & & \\
\hline
\end{tabular}

Also, the interaction between humic acid application and NK treatment had a significant effect on top length in the first season only. It was clear from the obtained results that the highest mean value of top length/plant $(48.1 \mathrm{~cm}$ in the first season) was obtained from $\mathrm{H}_{1} \mathrm{~F}_{9}$ (humic acid soil application and $90 \mathrm{~kg} \mathrm{~N}+100 \mathrm{~kg}$ $\mathrm{K}_{2} \mathrm{O} / \mathrm{fed}$.). While, the lowest mean value in the respect $(37.3 \mathrm{~cm})$ was obtained from $\mathrm{H}_{0} \mathrm{~F}_{1}$ (without humic acid and $30 \mathrm{~kg} \mathrm{~N}+0 \mathrm{~kg}$ $\mathrm{K}_{2} \mathrm{O} /$ fed.).

\section{3-Top fresh weight /plant (g):}

Data recorded in Table 3 clear that top fresh weight/plant was significantly affected by humic acid application in the both seasons. The application of humic acid on soil did not differ significantly from the foliar spray of humic acid. The greatest value of top fresh weight/plant (814.44 and $485.78 \mathrm{~g}$ in the first and second seasons, respectively) were derived from $\mathrm{H}_{2}$ (foliar application) and $\mathrm{H}_{1}$ (soil application). Humic substances such as humate, humic acid and fulvic acid, play avital role in soil fertility and plant nutrition. This tendency was recorded by El-gamal et al (2016), Enan et al (2016), Nemeata Alla et al (2018), Ozbay and Murat (2018) and Thalooth et al (2019). Data collected in the Table 3 reveal that increasing $\mathrm{NK}$ rates from $\mathrm{F}_{1}(30 \mathrm{~kg} \mathrm{~N}+0 \mathrm{~kg} \mathrm{~K} 2 \mathrm{O}$ /fed.) to $\mathrm{F}_{9}\left(90 \mathrm{~kg} \mathrm{~N}+100 \mathrm{~kg} \mathrm{~K}_{2} \mathrm{O} /\right.$ fed.) occurred a significant increase in top fresh weight in the both seasons. Application of $\mathrm{F}_{9}$ gave the highest mean values of top fresh weight/plant (969.33 and $650.11 \mathrm{~g}$ in the first and second seasons, respectively). This may be due to nitrogen affects growth and in turn on yield through its effect on cell division, expansion, and elongation resulting to large leaves and enhanced yield (Onyango, 2002). These findings were in harmony with those reported by Geweifel and Aly (1996), Abdallah and Yassen (2008), Attia et al (2011), Hussein and Hanan (2012), Kassab et al (2012) Sakr et al (2014), Abdelaal and sahar (2015) Merwad (2015), Enan et al (2016), Khatab et al (2016), Aly et al (2017), Abdel-Lateef (2018) and Nemeata Alla et al (2018) seasons.

Concerning the interaction between humic acid treatment and $\mathrm{NK}$ treatment $(\mathrm{H} \times \mathrm{F})$ effect, data in Table 3 show significant effect on top fresh weight/plant in both seasons. The highest main 
values of top fresh weight/plant (1100 and 701g in the two respective seasons) were obtained from $\mathrm{H}_{2} \mathrm{~F}_{9}$ and $\mathrm{H}_{1} \mathrm{~F}_{9}$ respectively. Otherwise, the lowest mean values in this respect (490 and $227 \mathrm{~g}$ ) were obtained from $\mathrm{H}_{0} \mathrm{~F}_{1}$ treatment.

Table 3: Effects of humic acid, NK treatments and their interaction on top fresh weight/plant $(\mathrm{g})$ of fodder beet in 2016-2017 and 2017-2018.

\begin{tabular}{|c|c|c|c|c|c|c|c|c|}
\hline \multirow{3}{*}{$\begin{array}{l}\text { NK } \\
\text { Treatments } \\
\text { (F) }\end{array}$} & \multicolumn{4}{|c|}{$2016-2017$} & \multicolumn{4}{|c|}{$2017-2018$} \\
\hline & \multicolumn{8}{|c|}{ Humic acid treatments $(\mathrm{H})$} \\
\hline & $\begin{array}{l}\mathrm{H}_{0} \\
\text { without } \\
\text { humic acid }\end{array}$ & $\begin{array}{l}\mathrm{H}_{1} \\
\text { Soil } \\
\text { application }\end{array}$ & $\begin{array}{l}\mathrm{H}_{2} \\
\text { foliar } \\
\text { application }\end{array}$ & Mean & $\begin{array}{l}\mathrm{H}_{0} \\
\text { without } \\
\text { humic acid }\end{array}$ & $\begin{array}{l}\mathrm{H}_{1} \\
\text { Soil } \\
\text { application }\end{array}$ & $\begin{array}{l}\mathrm{H}_{2} \\
\text { foliar } \\
\text { application }\end{array}$ & Mean \\
\hline $\mathrm{F}_{1}(30 \mathrm{~kg} \mathrm{~N}+0 \mathrm{~kg} \mathrm{~K} / \mathrm{fed})$ & 490 & 634 & 630 & 585 & 227 & 354 & 341 & 307 \\
\hline $\mathrm{F}_{2}(30 \mathrm{~kg} \mathrm{~N}+50 \mathrm{~kg} \mathrm{~K} / \mathrm{fed})$ & 540 & 701 & 700 & 647 & 354 & 363 & 362 & 360 \\
\hline $\mathrm{F}_{3}(30 \mathrm{~kg} \mathrm{~N}+100 \mathrm{~kg} \mathrm{~K} / \mathrm{fed})$ & 602 & 866 & 850 & 773 & 460 & 512 & 501 & 491 \\
\hline $\mathrm{F}_{4}(60 \mathrm{~kg} \mathrm{~N}+0 \mathrm{~kg} \mathrm{~K} / \mathrm{fed})$ & 500 & 716 & 700 & 639 & 320 & 334 & 341 & 332 \\
\hline $\mathrm{F}_{5}(60 \mathrm{~kg} \mathrm{~N}+50 \mathrm{~kg} \mathrm{~K} / \mathrm{fed})$ & 550 & 776 & 750 & 692 & 400 & 501 & 493 & 464 \\
\hline $\mathrm{F}_{6}(60 \mathrm{~kg} \mathrm{~N}+100 \mathrm{~kg} \mathrm{~K} / \mathrm{fed})$ & 650 & 949 & 910 & 836 & 500 & 594 & 572 & 555 \\
\hline $\mathrm{F}_{7}(90 \mathrm{~kg} \mathrm{~N}+0 \mathrm{~kg} \mathrm{~K} / \mathrm{fed})$ & 591 & 800 & 800 & 730 & 400 & 490 & 503 & 464 \\
\hline $\mathrm{F}_{8}(90 \mathrm{~kg} \mathrm{~N}+50 \mathrm{~kg} \mathrm{~K} / \mathrm{fed})$ & 650 & 904 & 890 & 815 & 444 & 52 & 543 & 503 \\
\hline $\mathrm{F}_{9}(90 \mathrm{~kg} \mathrm{~N}+100 \mathrm{~kg} \mathrm{~K} / \mathrm{fed})$ & 900 & 908 & 1100 & 969 & 600 & 701 & 650 & 650 \\
\hline Mean & 608 & 806 & 814 & & 412 & 486 & 478 & \\
\hline \multicolumn{9}{|l|}{ LSD 0.05} \\
\hline $\mathrm{H}$ & 142.23 & & & & 42.93 & & & \\
\hline $\mathrm{F}$ & 60.101 & & & & 71.34 & & & \\
\hline $\mathrm{H} \times \mathrm{F}$ & 278.00 & & & & 113.60 & & & \\
\hline
\end{tabular}

\section{4-Top dry weight /plant (g):}

Averages of top dry weight/plant as affected by humic acid application, NK treatment and their interaction in the two seasons are illustrated in Table 4. Over NK treatment, the $\mathrm{H}_{0}$ treatment (without humic acid) decreased evidently and significantly top dry weight/plant comparing with the application of humic acid (soil or foliar), which (2017). did not differ significantly from each other in this respect. Top dry weight/plant under $\mathrm{H}_{1}$ surpassed those under $\mathrm{H}_{0}$ by $30.9 \%$ in the first season. The respective percentage of increments in top dry weight/plant under $\mathrm{H}_{2}$ over $\mathrm{H}_{0}$ attained $43.6 \%$. This result in accordance with that found by El-gamal et al (2016), Hoda et al (2016), Enan et al (2016) and Ozbay \& Murat (2018).

Table 4: Effects of humic acid, NK treatments and their interaction on top dry weight/plant (g) of fodder beet in 2016-2017 and 2017-2018 seasons.

\begin{tabular}{lll}
\hline NK & $2016-2017$ & 2017- 2018 \\
\cline { 2 - 3 } Treatments & Humic acid treatments $(\mathrm{H})$ & \\
\cline { 2 - 2 }
\end{tabular}




\begin{tabular}{lllllllll}
\cline { 2 - 8 }$(\mathrm{F})$ & $\begin{array}{l}\mathrm{H}_{0} \\
\text { without } \\
\text { humic acid }\end{array}$ & $\begin{array}{l}\mathrm{H}_{1} \\
\text { Soil } \\
\text { application }\end{array}$ & $\begin{array}{l}\mathrm{H}_{2} \\
\text { foliar } \\
\text { application }\end{array}$ & Mean & $\begin{array}{l}\mathrm{H}_{0} \\
\text { without } \\
\text { humic acid }\end{array}$ & $\begin{array}{l}\mathrm{H}_{1} \\
\text { Soil } \\
\text { application }\end{array}$ & $\begin{array}{l}\mathrm{H}_{2} \\
\text { foliar } \\
\text { application }\end{array}$ & Mean \\
\hline $\mathrm{F}_{1}(30 \mathrm{~kg} \mathrm{~N}+0 \mathrm{~kg} \mathrm{~K} / \mathrm{fed})$ & 55.19 & 73.72 & 79.48 & 69.47 & 25.41 & 42.54 & 38.68 & 35.54 \\
$\mathrm{~F}_{2}(30 \mathrm{~kg} \mathrm{~N}+50 \mathrm{~kg} \mathrm{~K} / \mathrm{fed})$ & 62.46 & 77.81 & 84.45 & 74.91 & 39.45 & 43.35 & 40.39 & 41.06 \\
$\mathrm{~F}_{3}(30 \mathrm{~kg} \mathrm{~N}+100 \mathrm{~kg} \mathrm{~K} / \mathrm{fed})$ & 63.19 & 97.25 & 100.86 & 87.10 & 58.14 & 62.26 & 57.61 & 59.34 \\
$\mathrm{~F}_{4}(60 \mathrm{~kg} \mathrm{~N}+0 \mathrm{~kg} \mathrm{~K} / \mathrm{fed})$ & 53.78 & 77.97 & 81.26 & 71.00 & 37.95 & 39.55 & 39.33 & 38.94 \\
$\mathrm{~F}_{5}(60 \mathrm{~kg} \mathrm{~N}+50 \mathrm{~kg} \mathrm{~K} / \mathrm{fed})$ & 58.61 & 74.12 & 87.28 & 73.34 & 44.84 & 55.94 & 57.11 & 52.63 \\
$\mathrm{~F}_{6}(60 \mathrm{~kg} \mathrm{~N}+100 \mathrm{~kg} \mathrm{~K} / \mathrm{fed})$ & 68.62 & 91.50 & 106.09 & 88.74 & 60.69 & 70.21 & 69.43 & 66.78 \\
$\mathrm{~F}_{7}(90 \mathrm{~kg} \mathrm{~N}+0 \mathrm{~kg} \mathrm{~K} / \mathrm{fed})$ & 65.78 & 84.90 & 87.35 & 79.34 & 45.13 & 54.58 & 60.40 & 53.37 \\
$\mathrm{~F}_{8}(90 \mathrm{~kg} \mathrm{~N}+50 \mathrm{~kg} \mathrm{~K} / \mathrm{fed})$ & 67.92 & 91.98 & 98.07 & 85.99 & 57.39 & 59.74 & 62.20 & 59.77 \\
$\mathrm{~F}_{9}(90 \mathrm{~kg} \mathrm{~N}+100 \mathrm{~kg} \mathrm{~K} / \mathrm{fed})$ & 92.27 & 100.26 & 118.95 & 103.83 & 65.70 & 80.88 & 81.08 & 75.89 \\
Mean & 65.31 & 85.50 & 93.76 & & 48.30 & 56.56 & 56.25 & \\
\hline LSD 0.05 & & & & & & & & \\
$\mathrm{H}$ & 16.77 & & & & $\mathrm{NS}$ & & & \\
$\mathrm{F}$ & 29.46 & & & & 6.63 & & & \\
$\mathrm{H}$ x F & & & & & & & & \\
\hline
\end{tabular}

Over humic acid treatments, data in Table 4 indicate that top dry weight/plant increased as NK fertilizers rates increased up to $\mathrm{F}_{9}(90 \mathrm{~kg} \mathrm{~N}$ $+100 \mathrm{~kg} \mathrm{~K}_{2} \mathrm{O} / \mathrm{fed}$.) in the both seasons. Application of $\mathrm{F}_{9}$ gave the highest mean values of top dry weight/plant (103.83 and $75.89 \mathrm{~g}$ in the two respective seasons). This may be due to nitrogen affects growth and in turn on yield through its effect on cell division, expansion, and elongation resulting to large leaves. These findings were in harmony with those reported by Abdallah and Yassen (2008), Attia et al (2011), Hussein and Hanan (2012), Kassab et al (2012), Sakr et al (2014), Merwad (2015), Enan et al (2016), Khatab et al (2016) and AbdelLateef (2018).

The interaction between humic acid treatment and NK treatment $(\mathrm{H} \times \mathrm{F})$ was significant in the both seasons (Table 4). The highest mean values of top dry weight/plant (118.95 and $81.08 \mathrm{~g}$ in the two respective seasons) were obtained from $\mathrm{H}_{2} \mathrm{~F}_{9}$. On the contrary, the lowest mean values of top dry weight/plant values (55.19 and $25.41 \mathrm{~g}$ in the two respective seasons) were obtained from $\mathrm{H}_{0} \mathrm{~F}_{1}$.

\section{5- Root length (cm):}

Data in Table 5 show that the application of humic acid on soil did not differ significantly from the foliar spray of humic acid. Root length significantly affected by humic acid application in the second season only. Soil application of humic acid significantly increased root length by $8.9 \%$, in the second season, compare with untreated plants. Root length in the second season affected by the level of humic acid and the longer root $(29.4 \mathrm{~cm})$ was obtained from humic acid soil application and the shorter $(27 \mathrm{~cm})$ was observed without humic acid. These results are agreement with those obtained by Shaban et al (2014), Zizy Abbas et al (2014), El-gamal et al (2016), Hanan and Mohamed (2017) Ozbay and Murat (2018) and Thalooth et al (2019).

Data in Table 5 focus that NK fertilizer had a significant effect on root length in the both seasons. The high level of NK $(90 \mathrm{~kg} \mathrm{~N}+100 \mathrm{~kg}$ $\mathrm{K}_{2} \mathrm{O} /$ fed.) gave the highest mean values of root length $(26.40$ and $34.40 \mathrm{~cm}$, in the first and second seasons respectively). Such effect of NK may be refer to its role in improving cell 
division and elongation which reflected on root elongation. These results are in according to Ibrahim et al (2002), Turk (2010), Albayrak and Yuksel (2010), Shalaby et al (2011), Hussein and Hanan (2012), Kassab et al (2012), Eman El-Sarag (2013), Shaban et al (2014), Abdelaal and sahar (2015), Merwad (2015), Nemeata Alla (2016), Mehanna et al (2017) and, AbdelLateef (2018).

The interaction between humic acid treatment and $\mathrm{NK}$ treatment $(\mathrm{H} \times \mathrm{F})$ was significant on root length in the both seasons. The highest mean values of root length (27 and $36 \mathrm{~cm}$ in the two respective seasons) were obtained from soil application of humic acid and $90 \mathrm{~kg} \mathrm{~N}+100 \mathrm{~kg} \mathrm{~K} 2 \mathrm{O} /$ fed. $\left(\mathrm{H}_{1} \mathrm{~F}_{9}\right)$. 6- Root diameter $(\mathrm{cm})$ :

Data in Table 6 shows that root diameter was significantly affected by humic acid treatment in the both seasons. The application of humic acid on soil did not differ significantly with the humic acid foliar treatment regarding the root diameter, and both treatments resulted significantly higher in their root diameter than the non humic acid treatment.

Table 5: Effects of humic acid, NK treatments and their interaction on root length $(\mathrm{cm})$ of fodder beet in 20162017 and 2017-2018 seasons.

\begin{tabular}{|c|c|c|c|c|c|c|c|c|}
\hline \multirow{3}{*}{$\begin{array}{l}\text { NK } \\
\text { Treatments } \\
\text { (F) }\end{array}$} & \multicolumn{4}{|c|}{ 2016-2017 } & \multicolumn{4}{|c|}{ 2017- 2018} \\
\hline & \multicolumn{8}{|c|}{ Humic acid treatments $(\mathrm{H})$} \\
\hline & $\begin{array}{l}\mathrm{H}_{0} \\
\text { without } \\
\text { humic acid }\end{array}$ & $\begin{array}{l}\mathrm{H}_{1} \\
\text { Soil } \\
\text { application }\end{array}$ & $\begin{array}{l}\mathrm{H}_{2} \\
\text { foliar } \\
\text { application }\end{array}$ & Mean & $\begin{array}{l}\mathrm{H}_{0} \\
\text { without } \\
\text { humic acid }\end{array}$ & $\begin{array}{l}\mathrm{H}_{1} \\
\text { Soil } \\
\text { application }\end{array}$ & $\begin{array}{l}\mathrm{H}_{2} \\
\text { foliar } \\
\text { application }\end{array}$ & Mean \\
\hline $\mathrm{F}_{1}(30 \mathrm{~kg} \mathrm{~N}+0 \mathrm{~kg} \mathrm{~K} / \mathrm{fed})$ & 18.00 & 20.00 & 20.00 & 19.33 & 19.33 & 23.67 & 23.00 & 22.00 \\
\hline $\mathrm{F}_{2}(30 \mathrm{~kg} \mathrm{~N}+50 \mathrm{~kg} \mathrm{~K} / \mathrm{fed})$ & 19.33 & 21.80 & 21.13 & 20.76 & 24.33 & 25.40 & 25.00 & 24.91 \\
\hline $\mathrm{F}_{3}(30 \mathrm{~kg} \mathrm{~N}+100 \mathrm{~kg} \mathrm{~K} / \mathrm{fed})$ & 22.20 & 24.00 & 23.00 & 23.07 & 29.33 & 32.00 & 31.00 & 30.78 \\
\hline $\mathrm{F}_{4}(60 \mathrm{~kg} \mathrm{~N}+0 \mathrm{~kg} \mathrm{~K} / \mathrm{fed})$ & 20.53 & 21.67 & 21.60 & 21.27 & 25.00 & 28.07 & 28.00 & 27.02 \\
\hline $\mathrm{F}_{5}(60 \mathrm{~kg} \mathrm{~N}+50 \mathrm{~kg} \mathrm{~K} / \mathrm{fed})$ & 22.00 & 23.00 & 22.53 & 22.51 & 25.80 & 28.67 & 28.67 & 27.71 \\
\hline $\mathrm{F}_{6}(60 \mathrm{~kg} \mathrm{~N}+100 \mathrm{~kg} \mathrm{~K} / \mathrm{fed})$ & 24.33 & 25.67 & 25.00 & 25.00 & 29.67 & 32.33 & 32.00 & 31.33 \\
\hline $\mathrm{F}_{7}(90 \mathrm{~kg} \mathrm{~N}+0 \mathrm{~kg} \mathrm{~K} / \mathrm{fed})$ & 22.47 & 23.00 & 22.60 & 22.69 & 28.80 & 28.67 & 27.33 & 28.27 \\
\hline $\mathrm{F}_{8}(90 \mathrm{~kg} \mathrm{~N}+50 \mathrm{~kg} \mathrm{~K} / \mathrm{fed})$ & 23.33 & 24.53 & 23.67 & 23.84 & 29.33 & 30.00 & 30.67 & 30.00 \\
\hline $\mathrm{F}_{9}(90 \mathrm{~kg} \mathrm{~N}+100 \mathrm{~kg} \mathrm{~K} / \mathrm{fed})$ & 25.67 & 27.00 & 26.67 & 26.44 & 31.80 & 36.00 & 35.33 & 34.38 \\
\hline Mean & 21.98 & 23.41 & 22.91 & & 27.04 & 29.42 & 29.00 & \\
\hline \multicolumn{9}{|l|}{ LSD 0.05} \\
\hline $\mathrm{H}$ & NS & & & & 0.87 & & & \\
\hline $\mathrm{F}$ & 2.92 & & & & 1.83 & & & \\
\hline $\mathrm{H} \times \mathrm{F}$ & 3.66 & & & & 3.17 & & & \\
\hline
\end{tabular}

Application of humic acid on soil increased root diameter by $12.6 \%$ and $17.4 \%$ in the first and second seasons, respectively compared with non-application of humic acid. These results are in good line with those obtained by Shaban et al (2014), Zizy Abbas et al (2014),
El-gamal et al (2016), Enan et al (2016), Ozbay and Murat (2018), Nemeata Alla et al (2018), Thalooth et al (2019) and Kandil et al (2020).

As for NK treatments, data in Table 6 indicate that NK had a significant effect on root 
diameter in the both seasons. The high levels of nitrogen and potassium treatment $\left(\mathrm{F}_{9}\right)$ surpassed significantly all other $\mathrm{NK}$ treatments. Applied of $90 \mathrm{~kg} \mathrm{~N}+100 \mathrm{~kg} \mathrm{~K} 2 \mathrm{O}$ /fed increased root diameter by $48.9 \%$ and $59.5 \%$ in the first and second seasons, respectively compared with the law rate of nitrogen and potassium $\left(30 \mathrm{~kg} \mathrm{~N}+0 \mathrm{~kg} \mathrm{~K}_{2} \mathrm{O}\right.$ /fed.). These results are in accordance with those obtained by Ibrahim et al (2002), Abdallah and Yassen (2008), Turk (2010), Albayrak and Yuksel (2010), Shalaby et al (2011), Hussein and Hanan (2012), Kassab et al (2012), Khogali et al (2012), Eman ElSarag (2013), Shaban et al (2014), Abdelaal and sahar (2015), Merwad (2015), Enan et al (2016), Nemeata Alla (2016), Aly et al (2017), Mehanna et al (2017), Abdel-Lateef (2018) and Nemeata Alla (2018).

The interaction between humic acid treatment and NK treatment $(\mathrm{H} \times \mathrm{F})$ exhibited significant for root diameter in the both seasons. The highest mean values of root diameter $(14.50$ and $14.30 \mathrm{~cm}$ in the two respective seasons) were obtained from $\mathrm{H}_{1} \mathrm{~F}_{9}$ in the both seasons. The significant response could be attributed to a different trend of response which was observed in plants of application humic acid under NK treatments.

\section{7- Root fresh weight/plant (g):}

Results given in Table 7 indicate that the application of humic acid on soil did not differ significantly with the humic acid foliar treatment. Soil application of humic acid significantly increased root fresh weight by $65.6 \%$ in the second season, compare with untreated plants. Humic acid application (soil or foliar) failed to be significant at $5 \%$ level of probability in the first season. These results may be due to that humic substances enhance the uptake of some nutrients, and improve the plant resistance to salinity. These results are explaining with those reported by Shaban et al (2014), Zizy Abbas et al (2014), El-gamal et al (2016), Enan et al (2016), Hoda et al (2016), Nemeata Alla et al (2018), Ozbay and Murat (2018) and Thalooth et al (2019).

Data collected in the Table 7 reveal that increasing $\mathrm{NK}$ rates from $\mathrm{N} 30 \mathrm{~K} 0 \mathrm{~kg} /$ fed.to N90K100 kg/fed occurred a significant increase in fresh weight of root in the both seasons. Application of $90 \mathrm{~kg} \mathrm{~N}+100 \mathrm{~kg} \mathrm{~K} 2 \mathrm{O}$ /fed gave the highest mean values of root fresh weight $(2299.78$ and $1793.00 \mathrm{~g} / \mathrm{plant}$ in the first and second seasons, respectively). This may be due to nitrogen affects growth and in turn on root weight through its effect on cell division, expansion, and elongation resulting to large leaves and enhanced root weight/plant. These findings were in harmony with those reported by Geweifel and Aly (1996), Abdallah and Yassen (2008), Attia et al (2011), Shalaby et al (2011), Hussein and Hanan (2012), Kassab et al (2012), Sakr et al (2014), Shaban et al (2014), Abdelaal and sahar (2015), Merwad (2015), Enan et al (2016), Khatab et al (2016), Aly et al (2017), Abdel-Lateef (2018) and Nemeata Alla (2018). The interaction between humic acid treatment and $\mathrm{NK}$ treatment $(\mathrm{H} \times \mathrm{F})$ was significant regarding root fresh weight trait in the both seasons (Table 7). The highest mean values of root weight/plant (2700.67 and $2086.33 \mathrm{~g} /$ plant in the two respective seasons) were obtained from $\mathrm{H}_{1} \mathrm{~F}_{9}$. These findings are in harmony with Enan et al (2016).

Table 6: Effects of humic acid, NK treatments and their interaction on root diameter $(\mathrm{cm})$ of fodder beet in 2016-2017 and 2017-2018 seasons. 


\begin{tabular}{|c|c|c|c|c|c|c|c|c|}
\hline \multirow{4}{*}{$\begin{array}{l}\text { NK } \\
\text { Treatments } \\
\text { (F) }\end{array}$} & \multicolumn{4}{|c|}{ 2016-2017 } & \multicolumn{4}{|c|}{ 2017-2018 } \\
\hline & \multicolumn{8}{|c|}{ Humic acid treatments $(\mathrm{H})$} \\
\hline & $\mathrm{H}_{0}$ & $\mathrm{H}_{1}$ & $\mathrm{H}_{2}$ & Mean & $\mathrm{H}_{0}$ & $\mathrm{H}_{1}$ & & Mean \\
\hline & $\begin{array}{l}\text { Without } \\
\text { humic acid }\end{array}$ & $\begin{array}{l}\text { Soil } \\
\text { application }\end{array}$ & $\begin{array}{l}\text { foliar } \\
\text { application }\end{array}$ & & $\begin{array}{l}\text { without } \\
\text { humic acid }\end{array}$ & $\begin{array}{l}\text { Soil } \\
\text { application }\end{array}$ & $\begin{array}{l}\text { foliar } \\
\text { application }\end{array}$ & \\
\hline $\mathrm{F}_{1}(30 \mathrm{~kg} \mathrm{~N}+0 \mathrm{~kg} \mathrm{~K} / \mathrm{fed})$ & 9.00 & 9.26 & 9.38 & 9.21 & 7.10 & 9.12 & 9.01 & 8.44 \\
\hline $\mathrm{F}_{2}(30 \mathrm{~kg} \mathrm{~N}+50 \mathrm{~kg} \mathrm{~K} / \mathrm{fed})$ & 9.41 & 9.85 & 9.68 & 9.65 & 8.03 & 9.31 & 9.30 & 8.91 \\
\hline $\mathrm{F}_{3}(30 \mathrm{~kg} \mathrm{~N}+100 \mathrm{~kg} \mathrm{~K} / \mathrm{fed})$ & 10.52 & 11.94 & 11.84 & 11.43 & 9.01 & 9.81 & 9.93 & 9.58 \\
\hline $\mathrm{F}_{4}(60 \mathrm{~kg} \mathrm{~N}+0 \mathrm{~kg} \mathrm{~K} / \mathrm{fed})$ & 9.50 & 10.67 & 11.50 & 10.59 & 8.19 & 9.90 & 9.90 & 9.34 \\
\hline $\mathrm{F}_{5}(60 \mathrm{~kg} \mathrm{~N}+50 \mathrm{~kg} \mathrm{~K} / \mathrm{fed})$ & 10.11 & 11.33 & 11.53 & 10.99 & 9.41 & 10.30 & 10.00 & 9.90 \\
\hline $\mathrm{F}_{6}(60 \mathrm{~kg} \mathrm{~N}+100 \mathrm{~kg} \mathrm{~K} / \mathrm{fed})$ & 11.67 & 13.41 & 13.50 & 12.86 & 10.00 & 11.02 & 10.93 & 10.65 \\
\hline $\mathrm{F}_{7}(90 \mathrm{~kg} \mathrm{~N}+0 \mathrm{~kg} \mathrm{~K} / \mathrm{fed})$ & 9.95 & 11.33 & 11.00 & 10.76 & 9.05 & 11.44 & 11.00 & 10.47 \\
\hline $\mathrm{F}_{8}(90 \mathrm{~kg} \mathrm{~N}+50 \mathrm{~kg} \mathrm{~K} / \mathrm{fed})$ & 10.50 & 12.01 & 12.01 & 11.51 & 10.34 & 12.20 & 11.51 & 11.35 \\
\hline $\mathrm{F}_{9}(90 \mathrm{~kg} \mathrm{~N}+100 \mathrm{~kg} \mathrm{~K} / \mathrm{fed})$ & 12.37 & 14.50 & 14.20 & 13.69 & 12.02 & 14.30 & 13.83 & 13.38 \\
\hline Mean & 10.34 & 11.59 & 11.63 & & 9.21 & 10.83 & 10.60 & \\
\hline \multicolumn{9}{|l|}{ LSD 0.05} \\
\hline $\mathrm{H}$ & 0.43 & & & & 0.32 & & & \\
\hline $\mathrm{F}$ & 0.62 & & & & 0.72 & & & \\
\hline $\mathrm{H} \times \mathrm{F}$ & 1.10 & & & & 1.25 & & & \\
\hline
\end{tabular}

Table 7: Effects of humic acid, NK treatments and their interaction on root fresh weight/plant (g) of fodder beet in 2016-2017 and 2017-2018

\begin{tabular}{|c|c|c|c|c|c|c|c|c|}
\hline \multirow{4}{*}{$\begin{array}{l}\mathrm{NK} \\
\text { Treatments } \\
\text { (F) }\end{array}$} & \multicolumn{4}{|c|}{$2016-2017$} & \multicolumn{2}{|c|}{$2017-2018$} & & \\
\hline & \multicolumn{8}{|c|}{ Humic acid treatments $(\mathrm{H})$} \\
\hline & \multirow{2}{*}{$\begin{array}{l}\mathrm{H}_{0} \\
\text { without } \\
\text { humic acid }\end{array}$} & \multirow{2}{*}{$\begin{array}{l}\mathrm{H}_{1} \\
\text { Soil } \\
\text { application }\end{array}$} & \multirow{2}{*}{$\begin{array}{l}\mathrm{H}_{2} \\
\text { foliar } \\
\text { application }\end{array}$} & \multirow[t]{2}{*}{ Mean } & \multirow{2}{*}{$\begin{array}{l}\mathrm{H}_{0} \\
\text { without } \\
\text { acid } \\
\end{array}$} & \multirow{2}{*}{$\begin{array}{l}\mathrm{H}_{1} \\
\text { Soil } \\
\text { application }\end{array}$} & \multirow{2}{*}{$\begin{array}{l}\mathrm{H}_{2} \\
\text { foliar } \\
\text { application }\end{array}$} & \multirow[t]{2}{*}{ Mean } \\
\hline & & & & & & & & \\
\hline $\mathrm{F}_{1}(30 \mathrm{~kg} \mathrm{~N}+0 \mathrm{~kg} \mathrm{~K} / \mathrm{fed})$ & 1095 & 1735 & 1745 & 1525 & 766 & 1214 & 1201 & 1060 \\
\hline $\mathrm{F}_{2}(30 \mathrm{~kg} \mathrm{~N}+50 \mathrm{~kg} \mathrm{~K} / \mathrm{fed})$ & 1275 & 1955 & 1900 & 1710 & 908 & 1626 & 1600 & 1378 \\
\hline $\mathrm{F}_{3}(30 \mathrm{~kg} \mathrm{~N}+100 \mathrm{~kg} \mathrm{~K} / \mathrm{fed})$ & 1498 & 2141 & 2123 & 1921 & 1102 & 1840 & 1799 & 1580 \\
\hline $\mathrm{F}_{4}(60 \mathrm{~kg} \mathrm{~N}+0 \mathrm{~kg} \mathrm{~K} / \mathrm{fed})$ & 1316 & 1831 & 1857 & 1668 & 824 & 1340 & 1340 & 1168 \\
\hline $\mathrm{F}_{5}(60 \mathrm{~kg} \mathrm{~N}+50 \mathrm{~kg} \mathrm{~K} / \mathrm{fed})$ & 1424 & 1900 & 1880 & 1735 & 908 & 1467 & 1340 & 1258 \\
\hline $\mathrm{F}_{6}(60 \mathrm{~kg} \mathrm{~N}+100 \mathrm{~kg} \mathrm{~K} / \mathrm{fed})$ & 1580 & 2293 & 2141 & 2004 & 1098 & 1907 & 1840 & 1615 \\
\hline $\mathrm{F}_{7}(90 \mathrm{~kg} \mathrm{~N}+0 \mathrm{~kg} \mathrm{~K} / \mathrm{fed})$ & 1393 & 1925 & 1911 & 1743 & 866 & 1399 & 1420 & 1228 \\
\hline $\mathrm{F}_{8}(90 \mathrm{~kg} \mathrm{~N}+50 \mathrm{~kg} \mathrm{~K} / \mathrm{fed})$ & 1475 & 2215 & 2089 & 1926 & 1033 & 1640 & 1673 & 1449 \\
\hline $\mathrm{F}_{9}(90 \mathrm{~kg} \mathrm{~N}+100 \mathrm{~kg} \mathrm{~K} / \mathrm{fed})$ & 1761 & 2701 & 2437 & 2300 & 1266 & 2086 & 2027 & 1793 \\
\hline Mean & 1424 & 2078 & 2009 & & 974 & 1613 & 1589 & \\
\hline \multicolumn{9}{|l|}{ LSD 0.05} \\
\hline $\mathrm{H}$ & \multicolumn{4}{|l|}{ NS } & \multicolumn{2}{|l|}{481.40} & & \\
\hline $\mathrm{F}$ & \multicolumn{4}{|l|}{357.00} & \multicolumn{2}{|l|}{246.90} & & \\
\hline $\mathrm{H} \times \mathrm{F}$ & \multicolumn{4}{|l|}{569.40} & \multicolumn{2}{|l|}{393.20} & & \\
\hline
\end{tabular}

Data in Table 8 indicate that humic acid treatments had a significant effect on root dry 
weight/plant in the both seasons. Application of humic acid on soil did not differ significantly with the humic acid foliar treatment. Application humic acid significantly increased root dry weight by $43.9 \%$ and $83.9 \%$ in the first and second seasons, respectively, compare with untreated plants. These results are in line with those reported by Shaban et al (2014), Zizy Abbas et al (2014), El-gamal et al (2016), Enan et al (2016), Hoda et al (2016) and Ozbay and Murat (2018).

Data collected in the Table 8 reveal that increasing nitrogen and potassium fertilizers rates from $\mathrm{N} 30 \mathrm{~K} 0 \mathrm{~kg} / \mathrm{fed}$. to N90K100 kg/fed. occurred a significant increase in dry weight of root in the two seasons. Application of $\mathrm{F}_{9}(90 \mathrm{~kg} \mathrm{~N}+100 \mathrm{~kg}$ $\mathrm{K}_{2} \mathrm{O}$ /fed.) gave the highest mean values of root dry weight/plant (351.44 and 238.90 $\mathrm{g} / \mathrm{plant}$ in the first and second seasons, respectively). The increase in plant dry weight due to increasing nitrogen rate may be attributed to synergistic effect of nitrogen on vegetative growth, number and area of leaves as well as photosynthesis rate which increased dry matter accumulation and stored in root. Also, potassium fertilizer amount led to positive effect on physiological processes such as respiration, transpiration, enzyme reaction and cells turgidity of plant size and growth and activity of meristemic tissues responsible for elongation. These results are in full accordance with those reported by Abdallah and Yassen (2008), Attia et al (2011), Hussein and Hanan (2012), Kassab et al (2012), Sakr et al (2014), Shaban et al (2014), Merwad (2015), Enan et al (2016), Khatab et al (2016). In the two growing seasons, the interaction between humic acid treatment and NK. In the two growing seasons, the interaction between humic acid treatment and NK treatments had a significant effect on root dry weight in the both seasons (Table 8). In the first season, the highest mean value of root dry weight (431.37g/plant) was produced from H1F9. Where, H2F9 gave the highest mean value of root dry weight $(307.09 \mathrm{~g} / \mathrm{plant})$ in the second season. These findings are in harmony with Enan et al (2016).

Table 8: Effects of humic acid, NK treatments and their interaction on root dry weight/plant (g) of fodder beet in 2016-2017 and 2017-2018 seasons. 


\begin{tabular}{|c|c|c|c|c|c|c|c|c|}
\hline \multirow{3}{*}{$\begin{array}{l}\text { NK } \\
\text { Treatments } \\
\text { (F) }\end{array}$} & \multicolumn{4}{|c|}{$2016-2017$} & \multicolumn{4}{|l|}{ 2017- 2018} \\
\hline & \multicolumn{8}{|c|}{ Humic acid treatments $(\mathrm{H})$} \\
\hline & $\begin{array}{l}\mathrm{H}_{0} \\
\text { without } \\
\text { humic acid }\end{array}$ & $\begin{array}{l}\mathrm{H}_{1} \\
\text { Soil } \\
\text { application }\end{array}$ & $\begin{array}{l}\mathrm{H}_{2} \\
\text { foliar } \\
\text { application }\end{array}$ & Mean & $\begin{array}{l}\mathrm{H}_{0} \\
\text { without humic } \\
\text { acid }\end{array}$ & $\begin{array}{l}\mathrm{H}_{1} \\
\text { Soil } \\
\text { application }\end{array}$ & $\begin{array}{l}\mathrm{H}_{2} \\
\text { foliar } \\
\text { application }\end{array}$ & Mean \\
\hline $\mathrm{F}_{1}(30 \mathrm{~kg} \mathrm{~N}+0 \mathrm{~kg} \mathrm{~K} / \mathrm{fed})$ & 182 & 283. & 267 & 244 & 890 & 166 & 169 & 141 \\
\hline $\mathrm{F}_{2}(30 \mathrm{~kg} \mathrm{~N}+50 \mathrm{~kg} \mathrm{~K} / \mathrm{fed})$ & 203 & 305 & 272 & 260 & 103 & 244 & 246 & 197 \\
\hline $\mathrm{F}_{3}(30 \mathrm{~kg} \mathrm{~N}+100 \mathrm{~kg} \mathrm{~K} / \mathrm{fed})$ & 226 & 322 & 315 & 288 & 125 & 263 & 252 & 214 \\
\hline $\mathrm{F}_{4}(60 \mathrm{~kg} \mathrm{~N}+0 \mathrm{~kg} \mathrm{~K} / \mathrm{fed})$ & 209 & 292 & 283 & 261 & 106 & 179 & 185 & 157 \\
\hline $\mathrm{F}_{5}(60 \mathrm{~kg} \mathrm{~N}+50 \mathrm{~kg} \mathrm{~K} / \mathrm{fed})$ & 220 & 294 & 296 & 270 & 122 & 178 & 194 & 165 \\
\hline $\mathrm{F}_{6}(60 \mathrm{~kg} \mathrm{~N}+100 \mathrm{~kg} \mathrm{~K} / \mathrm{fed})$ & 239 & 347 & 319 & 302 & 152 & 266 & 223 & 214 \\
\hline $\mathrm{F}_{7}(90 \mathrm{~kg} \mathrm{~N}+0 \mathrm{~kg} \mathrm{~K} / \mathrm{fed})$ & 213 & 266 & 306 & 262 & 118 & 178 & 206 & 167 \\
\hline $\mathrm{F}_{8}(90 \mathrm{~kg} \mathrm{~N}+50 \mathrm{~kg} \mathrm{~K} / \mathrm{fed})$ & 233 & 335 & 311 & 293 & 129 & 207 & 230 & 189 \\
\hline $\mathrm{F}_{9}(90 \mathrm{~kg} \mathrm{~N}+100 \mathrm{~kg} \mathrm{~K} / \mathrm{fed})$ & 275 & 431 & 348 & 351 & 149 & 261 & 307 & 239 \\
\hline Mean & 222 & 320 & 302 & & 122 & 216 & 224 & \\
\hline \multicolumn{9}{|l|}{ LSD 0.05} \\
\hline $\mathrm{H}$ & 85.95 & & & & 65.00 & & & \\
\hline $\mathrm{F}$ & 60.32 & & & & 46.00 & & & \\
\hline $\mathrm{H} \times \mathrm{F}$ & 96.04 & & & & 73.89 & & & \\
\hline
\end{tabular}

\section{Conclusion:}

The highest mean values of previous traits were obtained from the application of humic acid on soil compared with no application of humic acid. In addition, the highest values of top length, root length, root diameter and LA, top fresh \& dry weight and root fresh \& dry weight were obtained from F9 $(90 \mathrm{Kg} \mathrm{N} / \mathrm{fed}+$ $100 \mathrm{~kg} \mathrm{~K} 2 \mathrm{O} / \mathrm{fed})$. It is recommended to adding humic acid on soil and fertilization with $\mathrm{NK}$ by $90 \mathrm{Kg} \mathrm{N}$ and $100 \mathrm{~kg} \mathrm{~K} 2 \mathrm{O}$ per feddan for fodder beet under similar soil and climate conditions.

\section{REFERENCES}

Abdallah, E.F., and Yassen, A.A. (2008) 'Fodder beet productivity under fertilization treatments and water augmentation' Australian Journal of Basic and Applied Sciences, 2, pp. 282287.
Abd El-Aal, S.M. (1990) 'Effect of nitrogen, phosphorus and potassium fertilization on the productivity of fodder beet (Beta vulgaris, L.)'Egypt. J. of Agron., 15(1-2), pp. 159-170.

Abdelaal, Kh.A.A., Sahar, F.T. (2015) 'Response of sugar beet plant (Beta vulgaris L.) to mineral nitrogen fertilization and bio-fertilizers' International Journal of Current Microbiology and Applied Sciences; 2015. 4(9):677-688. 46.

Abdel-Lateef, A.A. (2018) 'Effect of Organic Manure and Potassium Fertilizer on Productivity and Quality of Fodder Beet (Beta vulgaris. L.) at South West Suez Canal' J. Plant Production, Mansoura Univ., Vol. 9 (2): $181-188$.

Abdel Mawgoud A, El Greadly M.R.N., Helmy, Y.I., Singer, S.M. (2007) 'Responses of tomato plants to different rates of humic based fertilizer and NPK 
fertilization' Journal of Applied Sciences

Research 3, pp. 169-174.

Abdel-Gwad, M.S.A., El-Aziz, T.K.A. and El-Galil, M.A.A. (2008) 'Effect of intercropping wheat with fodder beet under different levels of $\mathrm{N}$-application on yield and quality. Annals of Agric. Sci. (Cairo) 53 (2) pp. 353-362.

Aly, E.F.A., Soha, R.K. and Eman, M.A. (2017) 'Effect of Boron, Potassium and Calcium on Growth, Yield and Quality of TwoSugar Beet Varieties under Sandy Soil Conditions' J. Plant Production, Mansoura Univ., Vol. 8(6): 699 - 704.

Anuja, S. and Jayalakshmi, L. (2011) 'Effect of foliar application of organic nutrients and inorganic fertilizers on growth and yield of palak [Beta vulgaris (L.) var. bengalensis]. Research on Crops; 2011. 12(2): pp. 574-577.

Attia, A.N., Said, E.M., Seadh, S. E., Samia, S.E. and Ibrahim, M.E.M. (2011) 'Effect of sowing methods and weed control treatments on growth of sugar beet and weed characters under nitrogen fertilizer levels. J. Plant Production, Mansoura Univ., Vol. 2 (6): pp. 773 - 785.

EL-gamal, I.S., Abd El-Aal, M.M., ElDesouky, S.A., Khedr, Z.M. and Abo Shady, K.A (2016) 'Effect of some growth substances on growth, chemical compositions and root yield productivity of sugar beet (Beta vulgaris L.) plant. Middle East Journal of Agriculture Research ISSN 2077-4605, Volume: 05 | Issue: 02 | April-June | 2016 Pages: 171185.

El-Sarag E.I. (2013) Response of fodder beet cultivars to water stress and nitrogen fertilization in semi-arid regions. American-Eurasian J. Agric. \& Environ. Sci., 13 (9): 1168-1175, 2013, ISSN pp. 1818-6769.
Enan, S.A.A.M., Aly, E.F.A. and Badr, A. I. (2016) 'Effect of humic acid and potassium on yield and quality of some sugar beet varieties in sandy soil. J. Plant Production, Mansoura Univ., Vol. 7 (2), pp. 289- 297.

Fikru, T., Gerba, D., Getaneh, D., Gizawu, D., Getahun, G., Abera, I., Abdisa, C. (2017) 'Effect of Plant Spacing and Urea Fertilizer on Yield and Yield Components of Beetroot (Beta Vulgaris L.). Agricultural Development, 2(1): 1321. Asian Online Journal Publishing Group.

Geweifel, H.G.M., Aly, R.M. (1996) 'Effect of nitrogen and potassium fertilization treatments on growth, yield and quality of some fodder beet varieties. Annals of Agricultural Science, Moshtohor; 1996. 34(2):pp. 441-454.

Gamal, A.M. and Ragab, M.A. (2003) 'Effect of organic manure source and its rate on growth, nutritional status of trees and productivity of balady mandarin trees. Assiut J. Agric. Sci., 4: pp. 253-264.

Gomez, K.A. and Gomez, A.A. (1984) 'Statistical procedures for agricultural research. 2nd edition, john Willy and sons Inc. New York. 680p.

Haghighi, S., Saki nejad, T., Lack, S.H. (2013) 'Evalution of changes the qualitation \& quantitative yield of horse been (vicia faba) plant in the levels of humic Acid fertilizer) Life science journal, 8 .

Hanan, Y.M. and Mohamed, M.I.A (2017) 'Response of some sugar beet varieties to foliar application of boron and fulvic acid. Egypt. J. Biotechnol. Vol. 55, October.

Hoda, M.R.M.A. and Fatma, S.H.I. (2016)' Effectiveness of humic acid applicationin improving saline soil properties and fodder beet production. J.Soil Sci. and 
Agric. Eng., Mansoura Univ., Vol. 7 (9):pp. $623-634$.

Hussein, M.M.1., Hanan, S.S. (2012) 'Growth, yield and water use efficiency of fodder beet responses to the npk fertilizer and withholding irrigation. International Journal of Science and Research 22, pp. 2319-7064

Kandil, E.E., Nader R.A., Ashraf, A.A., Hayssam M.A. and Manzer H.S. (2020) 'Efficacy of Nanofertilizer, Fulvic Acid and Boron Fertilizer on Sugar Beet (Beta Vulgaris L.) yield and Quality. Society for Sugar Research \& Promotion 2020. Sugar

Tech https://doi.org/10.1007/s12355-02000837-8

Kassab, O.M., Orabi, S.A. and Abo Ellil, A.A. (2012) 'Physiological response to potassium application in fodder beet plant grown under water stress' Australian Journal of Basic and Applied Sciences, 6, 566-574.2012 ISSN 19918178.

Khogali, M.E., Ibrahim, Y.M. and El-Hag, M.G. (2012) 'Effect of nitrogen and spacing on growth of fodder beet (Beta vulgaris L.) cultivars under Sudan conditions. Journal of Pharmaceutical and Scientific Innovation (JPSI); 2012. 1(3):67-71.

Khatab, A.K., Nadia, M.H. and Amira, A.M. (2016) 'Impact of mineral, organic and bio fertilizers on growth, yield and quality of fodder beet under sandy soil conditions in North Sinai. J. Soil Sci. and Agric. Eng., Mansoura Univ., Vol. 7 (5): pp. 345 - 352 .

Ibrahim, M.R., Khalifa, M.A., Koriern, F.I. and Omer, E.H. (2002)'Yield and quality of sugar beet crop as affected by mid to late season drought and potassium fertilization at North Nile Delta, Egypt. J. Soil Sci. 42, NO. 1, pp. 87- 102.
Mehanna, H.M., Safi-naz S.Z. and Hussien, M.M. (2017) 'Influences of irrigation and fertilizer on growth and yield of two sugar beet varieties in Egypt. Middle East Journal of Agriculture Research ISSN 2077-4605, Volume: 06| Issue: 04| Oct.Dec. 2017 Pages:CC-CC.

Merwad, A.M.A. (2015) 'Effect of potassium fertilization and salicylic acid on yield, quality and nutrient uptake of sugar beet (Beta vulgaris L.) grown in saline soil' Malaysian Journal of Soil Science Vol. 19: pp. 95-105.

Mstat, V.4. (1986). 'Amicro computer program for the design management and analysis of agronomic research experiments' Michigan State University, USA.

Nemeata Alla, H.E.A. (2016) 'Yield and quality of sugar beet as affected by rates of nitrogen and yeast under the number of magenisem application. J. Plant Production, Mansoura Univ., Vol. 7 (8): pp. $821-828$.

Nemeata Alla, H.E.A., Sasy, A.H. and Samar, A.M.H. (2018) 'Effect of potassium humate and nitrogen fertilization on yield and quality of sugar beet in sandy soil. $J$. Plant Production, Mansoura Univ., Vol. 9 (4): pp. 333 - 338.

Niazi, B.H., Rozema, J., Broekman, R.A. and Salim, M. (2000) 'Dynamics of growth and water relations of fodder beet and sea beet in response to salinity. Journal of Agron.and Crop Sci. 184: pp. 101-109.

Noreldin.T., Sakr, H.O., Abdou, S. and Awad, H. (2016) 'Simulation of water management for fodder beet to reduce yield losses under late season drought' Food Science \& Technology Research Article. Noreldin et al., Cogent Food \& Agriculture (2016), 2: 1145031.

Özbay, S. and Murat, Y. (2018) 'Root Yield and quality of sugar beet under drip and 
sprinkler irrigation with foliar application of micronutrients' Araştırma Makalesi/Research Article ÇOMÜ Zir. Fak. Derg. 6 (1): pp. 105-114

Ozen, N., Cakir, A., Hasimoglu, S. and Aksoy, S. (1993) 'Yemler Bilgisive Yem Teknolojisi Ders Notlarý: 50. Ataturk Univ. Erzurum. Parlak, A.O. VE

Sahar, F.T. (2000) 'Effect of dates and forms of nitrogen fertilization on yield and quality of sugar beet under surface and spray irrigation methods in newly reclaimed areas. Ph.D. Thesis. Agron. Dept., Fac. Agric. Alex. Univ., Egypt.

Sakr, H.O., Awad, H.A., Seadh, S.E. and Abido, W.A.E. (2014) 'Influence of irrigation withholding and potassium levels on forage yields and its quality of fodder beet. Journal of Crop Science, 5, pp. $-116-125$.

Shaban, KH.A.H., Eman, M.A. and Dalia A.S. (2014) 'Impact of humic acid and mineral nitrogen fertilization on soil chemical properties and yield and quality of sugar beet under saline soil. J. Soil Sci. and Agric. Eng., Mansoura Univ., Vol. 5 (10): pp. 1335 - 1353.

Shalaby, N.M.E., Osman, A.M.H., AbdelFatah, E.M. (2011) 'Response of some sugar beet (Beta vulgaris L.) varieties to nitrogen fertilizer in sandy reclaimed soils. Bulletin of Faculty of Agriculture, Cairo University; 2011. 62(3):329-335.

Thalooth A.T., Tawfik, M.M., Elham A.B. and Magda H.M. (2019). Yield and quality response of some sugar beet (Beta vulgaris L.) varieties to humic acid and yeast application in newly reclaimed soil. Middle East Journal of Agriculture Research 8, pp. 56-65.

Turk, M. (2010) 'Effects of fertilization on root yield and quality of fodder beet (Beta Vulgaris var. Crassa Mansf.).
Bulgarian Journal of Agricultural Science, 16, pp. 212-219

Watson, D.j. and Watson, A.M. (1953)' Comparative physiological studies on the growth of field crop. III. Effect of infraction with Beet yellow. Ann. Appl. Biol., 5101.

Zamfir, I., Zamfir, M.C., Dihoru, A. and Dumitru, E. (2001) 'The long-term fertilization influence on both fodder beet yield and some features of argilluvial chernozem from burnas plain. Analele Institutului de Cercetaripentru Cerealesi Plante Tehnice, Fundulea, 68: pp. 289.

Zizy, M.A., Sakr, H.O., Rama, T.R. and Shaban, Kh.A. (2014) 'Effect of seedsoaking in polyethylene glycol and humic acid on the productivity and quality of fodder beet under soil salinity conditions. J. Soil Sci. and Agric. Eng., Mansoura Univ., Vol. 5 (7): pp. 10371047. 